\title{
Data security is crucial for Japanese science
}

\section{Rules that are based solely on voluntary guidelines will not gain the trust of the public.}

Sir - The Japanese parliament is currently discussing new data-protection legislation, the first to be introduced in Japan, which will provide scientists with a broad exemption from the proposed rules. This exemption has not been widely discussed, and few citizens are even aware of the issue. Although the biomedical research community and pharmaceutical industry initially indicated tacit consent, concerns are now being voiced.

We believe the bill does not constitute an adequate regulatory framework for privacy protection in biomedical research. Several ministries, agencies and scientific societies have, in the past, drafted guidelines that have increased awareness of ethical issues, such as informed-consent procedures and review by research ethics committees. Yet the scope of the existing guidelines is restricted and there is considerable confusion about how the rules would be applied. We fear that data protection based solely on voluntary guidelines is insufficient to win public trust.

Progress in large-scale human genome research has dramatically increased the amount and content of personal data used in many areas of biomedical research. Large online databases linking personal information with genomic and clinical data are now feasible. For example, BioBank UK (see Nature 417, 9; 2002) is seen by many observers as an important step forward for clinical-genomics research in Britain. But its success will depend on the participation of UK citizens. Such support is unlikely without a well-conceived scientific strategy and, equally important, a convincing legal and regulatory framework for privacy protection.

Assembling large-scale cohorts for genome research remains very difficult in Japan; we believe a more widespread sharing of resources is now inevitable. Yet without a coherent, transparent approach to data security and data protection, the Japanese public is unlikely to support efforts to build large databases containing medical information and lifestyle details linked with genetic samples, because of distrust and the perception that Japan's medical and scientific community is unable to govern itself.

An inadequate data-protection regime could harm progress in clinical genetics and other biomedical sciences in Japan for many years. The result could well be that Japanese scientists and enterprises go elsewhere - already, Japanese companies are choosing Singapore and even Mongolia for new clinical-genomics research facilities. The Japan Association of Bioindustries Executives, a group representing the chief executives of Japan's major biotechnology companies, has just released a statement (www.jba.or.jp/jabex) urging the government to strengthen genetic privacy protection.

We believe that large databases containing both genetic and medical information are inevitable for the future of biomedical research. But without adequate data protection or public trust, such databases are unlikely to be set up in Japan. For biomedical research to progress in Japan we, as members of its scientific and medical community, believe it is time for Japanese scientists to engage in a constructive public debate on this issue. Eitaka Tsuboi

President, Japan Medical Association, World Medical Association, 28-16, Honkomagome 2-chome, Bunkyo-ku, Tokyo 113-8621, Japan Other signatories to this letter:

Norie Kawahara (freelance journalist)

Tadahiro Mitsuishi (attorney-at-law)

Akira Oshima President, Japan Association of Cancer Registries Shohei Yonemoto Director, Center of Life Science and Society

\section{Collaboration can work if inequality is recognized}

Sir - Your News report "Science collaboration stymied by relentless Middle East conflict" (Nature 417, 209-210; 2002) mentioned my support for PalestinianIsraeli cooperation. I would like to expand on my views. The Palestinian-Israeli conflict is neither a scientific issue nor a personal conflict but a struggle between two peoples over the same land. Therefore neither scientific collaboration in itself nor the personal relationships developed therein can advance the cause of peace unless conflict-related issues are also addressed and resolved.

Israelis have a strong army, resources, freedom and control over the land; Palestinians have none of these. One is occupier and the other is occupied. This inequality underlies any interaction between Palestinians and Israelis, including scientific cooperation, and should be the framework for any constructive dialogue. Unfortunately, this imbalance is often replicated in the collaboration and becomes a cause of frustration and disengagement on the part of the Palestinian partner.

It requires courage and commitment to widen the partnership beyond the realm of science, to rise above the current polarization and high emotional pitch in our respective societies, to place universal humanitarian values above nationalism and to take a clear stand for justice and peace. Yet it is possible, as demonstrated by individual academics as well as organizations such as Médicins sans Frontières, Physicians for Human Rights and the Alliance of Middle Eastern Scientists and Physicians. An example of such a stand is a recent statement by 300 Israeli faculty members, which can be seen at www.seruv.org.il/ UniversitySupportEng.asp.

The international scientific community should become more actively engaged. Foreign collaborators and funding agencies can request a commitment to basic human rights and equality, and to the principle of equal academic freedom and access to education for Palestinians and Israelis. Israeli scientists and institutions should express solidarity with Palestinian universities under siege and use their political clout to assist them. All partners should insist on a return to negotiations based on UN resolutions and international law.

A boycott of Israeli science would be relatively easy but, in the long run, counterproductive. Much more challenging and important is to use scientific interactions creatively, to promote true reconciliation. Yehuda Tzfati

Alliance of Middle Eastern Scientists and Physicians and Department of Genetics, The Hebrew University of Jerusalem, Jerusalem 91904, Israel

\section{Scientific links support an unjust peace process}

Sir-Cooperation between Israeli and Palestinian academics since the 1993 Oslo peace agreement (see Nature 417, 209-210; 2002) has been primarily donor-led that is, imposed or strongly encouraged via the carrot of money in a money-starved environment, with the underlying assumption that such cooperation would assist the peace process.

This push for "Israeli-Palestinian scientific cooperation", as if science were divorced from society, was regarded by many Palestinian academics as suspect. Most Palestinians opposed a basically unjust and non-sustainable peace process, as recent events in the area clearly confirm.

Palestinian academics have been paying the very heavy price of occupation for many years, both personally and in the 
under-development of their institutions. More recently, the conditions of closure and siege have reduced our scientific endeavours to near-paralysis, leaving us unable to teach, let alone conduct research. I believe it would be more rational to work towards preserving Palestinian academic institutions against the Israeli army's onslaughts, and rebuilding them, before collaborating with Israeli academics.

To me, this seems the right moment to act, including endorsing boycotts, instead of turning to the easier yet ineffective paths of building personal relationships, scientific or otherwise. Boycotts have been effective in raising issues and influencing change.

Israeli and other academics need to stand up for the right of Palestinians to scientific and educational development, academic freedom and freedom of speech for all, not simply on one side of the border. Cooperation with individuals may make academics feel better, but is not helpful, and can possibly be harmful, in general terms. Saying no to academic boycotts may mean that academics are not willing to pay a price for their stated ideals. To many of us here, this translates as a de facto endorsement of the Israeli government's attempt to destroy 'anything Palestinian', including the academic institutions that these relationships are supposed to assist. Rita Giacaman Institute of Community and Public Health, Birzeit University, Palestine

\section{Did an academic boycott help to end apartheid?}

Sir - The assertion made by Steven and Hilary Rose in Correspondence (Nature $\mathbf{4 1 7}, 221,2002)$ that the boycott of South Africa by the world's academic communities "was instrumental in ending apartheid in South Africa" is a deception. Apartheid was actually terminated by two pivotal and interrelated political events.

First, the United States Congress, on 29 September 1986, overrode President Reagan's veto and imposed strict economic sanctions on South Africa. Second, F. W. de Klerk was elected president of South Africa on 14 September 1989. Two months later (16 November 1989), de Klerk announced the scrapping of the Separate Amenities Act, then, on 11 February 1990, freed Nelson Mandela from prison. The rest is historical detail.

So if the Roses, and the signatories of their petition, wish to bring Israel even further to its knees, they may need to persuade Europe and the United States to increase by an order of magnitude the stringency of the Arab-led international trade boycott of Israel that has been in place since 1948.

As it stands, the petitioners have not made a cogent argument for why they selected Israel alone - from the many imperfect nations of the world - for their proposed academic boycott.

George Fink

C/o Scotbrain, 78/22 Levi Eshkol,

Tel Aviv 69361, Israel

\section{Violence versus freedom}

Sir - I read with great interest your News story about academic cooperation during the recent violence here (Nature 417, 209-210; 2002). Unfortunately, scientific work has become another victim of the violence. A related point is that of freedom of movement.

For many years, Palestinians could travel fairly freely in Israel. Thousands worked here on a daily basis. The increase in terrorist attacks, especially the suicide bombings, has made this freedom of movement unwise and dangerous. Many innocent people, including scientists, suffer as a result. Israelis are forbidden by the Israeli government to visit the areas controlled by the Palestinian Authority, for their own safety. Israelis who visit Palestinian cities are likely to pay with their lives: hardly "freedom of movement".

I hope that we will manage to achieve a more rational, calm atmosphere in this part of the world - but I fear that it will take some time.

Joel Bigman

ELS Photonics, PO Box 252, Nesher 36602, Israel

\section{In support of scientific exchange}

The International Human Rights Network of Academies and Scholarly Societies (http://www4.nas.edu/oia/ oiahome.nsf/web/network) was created to address grave issues of science and human rights throughout the world. It aims to put into practice the professional duty of scientists and scholars to assist those colleagues whose human rights have been - or are threatened to be - infringed, and to promote and protect the independence of academies and scholarly societies worldwide. The basis of the network's activities is the universal declaration of human rights.

The network seeks to promote the free exchange of ideas and opinions among scientists and scholars in all countries and, thereby, to stimulate the development of collaborative educational, research and human-rights endeavours within academies and the institutions with which they are affiliated.

Moratoria on scientific exchanges based on nationality, race, sex, language, religion, opinion and similar factors thwart the network's goals. They would deny our colleagues their rights to freedom of opinion and expression; interfere with their ability to exercise their bona fide academic freedoms; inhibit the free circulation of scientists and scientific ideas; and impose unjust punishment. They would also be an impediment to the instrumental role played by scientists and scholars in the promotion of peace and human rights.

This statement, although that of a general principle with universal applicability, was prompted by a petition (see Nature 417, 1 and 221-222; 2002) that advocates a moratorium on all grants and contracts to Israel from European cultural and research institutions. The moratorium being advocated, although surely well-intentioned, is misguided and inevitably counterproductive.

We all look forward to an equitable solution to the crisis in the Middle East, with lasting peace and stability for both Israel and the Palestinian Authority. But the strongest impact of a moratorium would, rather than influencing Israeli policy-makers, seriously and unfairly harm our scientific colleagues in Israel - many of whom have actively promoted peace through collegial engagement and open communication among academic centres in the region.

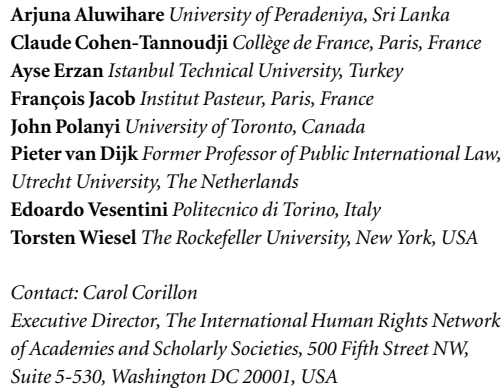

This statement was issued on 28 April 2002 by the members of the executive committee of the International Human Rights Network of Academies and Scholarly Societies. It was sent privately to some 60 national academies affiliated with the network. In response to a request by Nature, the committee (whose members' institutions are listed for identification purposes only) has agreed to its publication - Editor, Correspondence. 